\title{
Collective action and participation in irrigation water management: A case study of Mooi River Irrigation Scheme in KwaZulu-Natal Province, South Africa
}

\author{
B Muchara'* , G Ortmann' ${ }^{1}$, E Wale ${ }^{1}$ and M Mudhara' \\ School of Agricultural, Earth and Environmental Sciences, University of KwaZulu-Natal, Private Bag X01, Scottsville 3209, Pietermaritzburg, South Africa
}

\section{ABSTRACT}

\begin{abstract}
In line with the current focus of most developing countries to transfer management of communal irrigation schemes from state to users, an understanding of the determinants of farmer participation in collective activities forms the basis to improve the management of previously government-funded schemes, which are characterised by poor maintenance and performance when farmers are left to manage the schemes on their own. Cross-sectional data collected from 307 respondents in the Mooi River Irrigation Scheme (MRIS) in KwaZulu-Natal were used to identify the determinants of farmer participation in collective activities. The results of the Tobit and Ordered Probit models suggest that collective activities are negatively affected by low farmer-literacy levels. Number of consecutive days that farmers spend without access to irrigation water per week was used as a proxy for water scarcity, and was confirmed to be a significant determinant of farmer participation. The existing incentives for water-users in the MRIS need to be improved to encourage farmer participation in collective water management. This calls for strengthening of local water management systems and institutional policies to ensure maximum benefits from participating in collective activities. The study noted the complexity of managing common pool resources at a localised level, and pointed to the need to further understand the institutional dynamics in which smallholder irrigation farmers operate.
\end{abstract}

Keywords: Collective action, participation intensity, smallholder irrigation scheme, South Africa

\section{INTRODUCTION}

Small-scale irrigation is key to rural livelihoods and food security in developing economies (Sinyolo et al., 2014), particularly in regions associated with low and erratic rainfall and high evaporative demand, which limits dryland crop production (Hassan, 2011). However, despite the huge government investments in the establishment and refurbishment of smallholder irrigation schemes, some schemes face collapse soon after the withdrawal of state support (Cousins, 2013). Many countries have therefore embarked on a process to transfer the management of state-managed irrigation systems from government agencies to water users through implementing irrigation management transfer (IMT) and participatory irrigation management (PIM) policies (Perret, 2002; Arun et al., 2012; Gomo et al., 2014) The rationale for embarking on IMT is to relieve the government of the financial burden of funding recurrent expenditures for irrigation, improve the maintenance of irrigation facilities and the irrigation service, promote a culture of self-reliance among farmers in irrigation schemes and enhance the productivity of irrigated land and water (Hassan, 2011).

The implementation of IMT policy in most countries has been confronted with numerous challenges. For instance, Fujiie et al. (2005) noted that service of national irrigation systems deteriorated after the reduction in state agencies' operation and maintenance activities because irrigators in south and southeast Asia could not meet all the costs of operation

\footnotetext{
To whom all correspondence should be addressed

+27 73 527-8788; e-mail: mucharab@gmail.com

Received 29 November 2013; accepted in revised form 6 October 2014.
}

and maintenance from their farming activities. Similarly, smallholder irrigation schemes in South Africa were planned and established following a centralised state design system (Fanadzo et al., 2010). High levels of dependence on government support among smallholder irrigation farmers, accompanied by weak local institutions, lack of information regarding farmers' production strategies, low participation as well as poor maintenance and performance when farmers are left to manage previously government-funded schemes, are recurrent problems in South Africa (Perret, 2002; Mnkeni et al., 2010; Fanadzo, 2012; Reinders et al., 2013). The aforementioned challenges of managing SISs have given rise to the need to explore the level of participation in collective activities at scheme level, as a basis for ensuring effective smallholder irrigation management. The collective action concept coined by Olson (1965) is popularly applied in the management of common pool resources like irrigation schemes. However, due to institutional failures and lack of compliance to rules governing schemes, some schemes degenerate into open access resources, a problem defined by Hardin (1968) in the tragedy of the commons model. Hardin's model assumes the inability of individuals to cooperate to achieve outcomes superior to those achieved by individual actors. Hardin's theory was strongly contested by Ostrom through the collective action theory. The underlying assumption about collective participation is that those who participate have a stake in the final outcome (Ostrom, 2010). Therefore, it can be argued that customary rules and agreed norms in rural communities result in CPRs that are well preserved and utilised through the collective action of local appropriators (Ostrom, 1991; Ito, 2012). According to Wade (1987), canal water is a common-pool resource with a potentially high transaction cost of excluding a landowner with commandable land. 


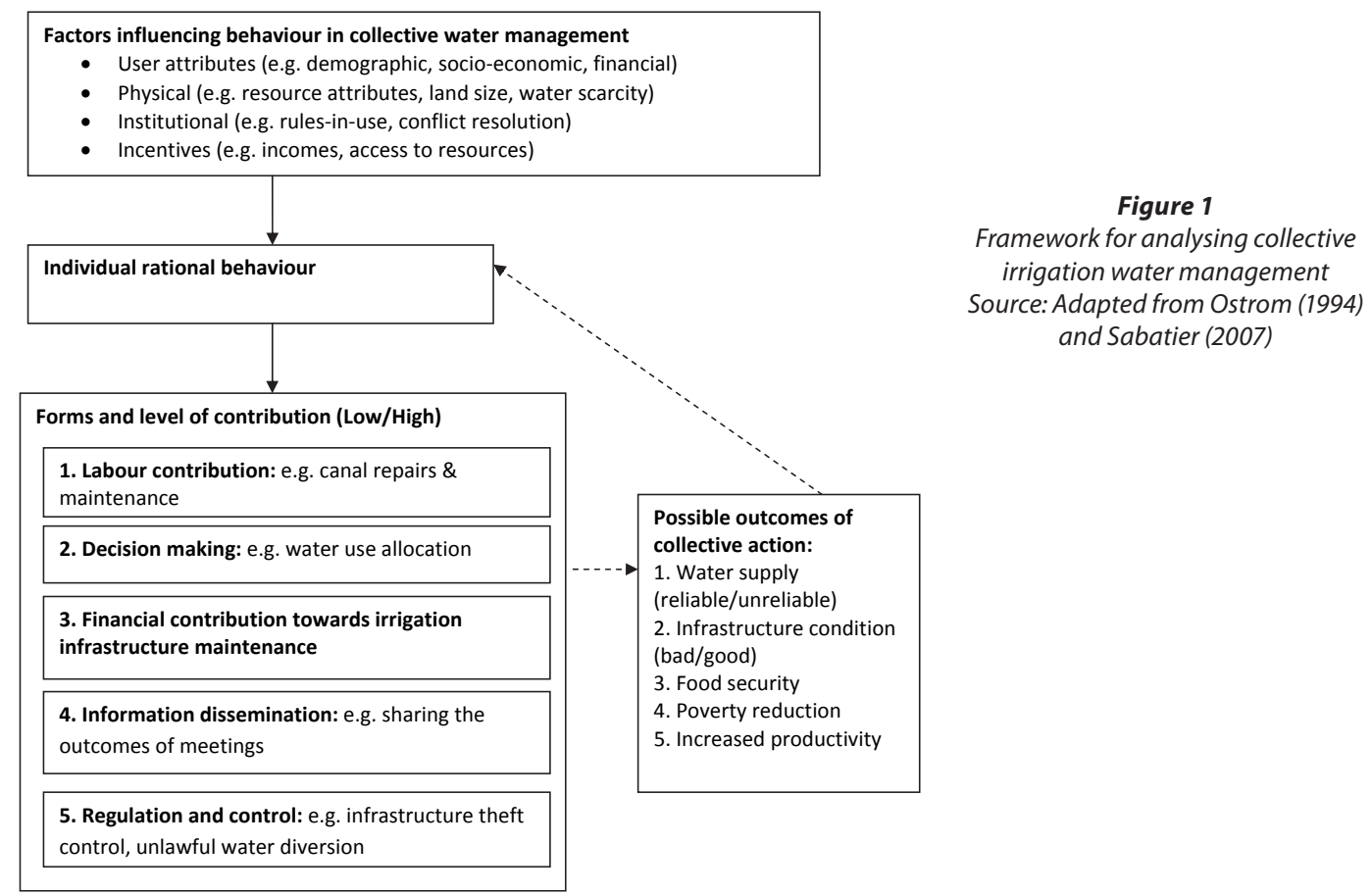

Consumption is subtractive, i.e., water applied to one farmer's land is not simultaneously available to other farmers or users (Wade, 1987).

Since 1997, the South African Government has focused on IMT of smallholder schemes from Government to plot holders and the rehabilitation of infrastructure (Cousins, 2013). This was later enshrined in the South African National Water Act (No. 36 of 1998), and emphasises the need for farmer participation in irrigation water management through water user associations (WUAs). As such, modern irrigation management systems that involve farmers in their planning, operation and maintenance are important, since most irrigation agencies cannot manage schemes efficiently without their support (Bacha et al., 2011).

The Mooi River Irrigation Scheme (MRIS) in KwaZuluNatal Province is one of several government smallholder irrigation schemes (SIS) developed in former homeland areas of South Africa during the apartheid era, mostly for community food supply purposes. As noted by Perret (2002), from the early 1990s most of such schemes in South Africa faced serious problems and an uncertain future, owing to low yields, deteriorating infrastructure, limited access to services, weak and unclear institutions regarding water and land, and lack of support. The need for collective participation in canal water management in MRIS is increasingly visible and is mandatory, unlike in the marketing of produce where farmers have a choice of participating or not.

The study sought to understand the various ways in which respondents participate as well as the level of participation in collective management of irrigation. This is further expanded by identifying the determinants of farmer participation in the collective activities as a basis to inform smallholder irrigation management policy. The paper comprises of 4 main sections. The following section presents the methodological framework, wherein the conceptual framework, description of the study site, sampling, and analytical methods are explained. This is followed by the empirical results of the regression models, and finally the conclusions and recommendations.

\section{METHODOLOGY}

\section{Theoretical and conceptual framework}

The importance of collective action in the management of common pool resources like irrigation schemes is vital and cannot be overemphasised. Weirich (2008) argued that failure to monitor group or organisational activities involving several people may lead to the group degenerating into chaos and anarchy. The assumption underlying this view is that individuals involved in group activities invariably make decisions based on self-interest rather than the common good if their actions are not monitored and action taken if individual decisions result in collective loss/tragedy. This assumption finds justification in rational choice theory, which predicts that individuals will act in ways that maximise their personal utility without any regard of the common good. Although MRIS like most schemes is a common pool resource (CPR), lack of rule enforcement and institutional failures to exclude non-irrigators, e.g. livestock owners, brick makers, etc., from accessing canal water, lead to the resource being open access. Hardin (1968) explained this scenario in his theory 'tragedy of the commons', wherein individuals with access to a common resource over-exploit it in their pursuit of personal gain, and thus end up depleting the resource completely, resulting in a tragedy common to all. In the current study, the tragedy can manifest itself in the form of infrastructure decay, water shortages and poor yields. On the other hand, Ostrom (2007) argued that given the right conditions, individuals and groups behave rationally and can work towards the common good even if it means foregoing personal gains. However, individual utility maximisation is regarded as a necessary condition of rationality, subject to constraints on the goals (Weirich, 2008). Figure 1 illustrates the postulated relationship among factors influencing individual behaviour towards collective activities, the various ways through which individuals contribute, and the possible outcomes of such behaviours. 
The collective action theory finds relevance in the present era of IMT, where a group of farmers sharing water resources are supposed to cooperate in order to maximise benefits from the resource. Based on Ostrom (2010), the three underlying assumptions of collective action are that: participants have common knowledge about the structure of payoffs to be received by all individuals under the combination of collective actions; decisions are made independently and simultaneously; and no external actor or central authority is present to enforce agreements among participants.

The nature and intensity of individual participation in collective water management activities is influenced by personal attributes, resource attributes, institutional setting and the incentive systems (Fig. 1). Members participate in collective activities through contributing labour, finance, decision making, information dissemination as well as regulation and control (Van der Zaag and Rap, 2012). However, the levels of contribution vary across members of the group depending on individual decisions and resource constraints. This gave rise to the need to measure individual intensity of participation in irrigation scheme management. The analytical framework considers the outcomes as important measures of collective action. The outcomes, that include reliability in water supply, infrastructure condition, food security, poverty reduction and incomes, may impact directly or indirectly on the way members perform collective activities. Undesirable outcomes hinder collective action activities, while positive outcomes can potentially motivate member participation in collective activities.

\section{Description of study area and sampling design}

The study was conducted in the MRIS located in Msinga Local Municipality, KwaZulu-Natal, South Africa (SA). The scheme consists of 15 blocks that run along the Mooi River. Irrigation water is diverted from the Mooi River along a concrete-lined canal to supply downstream crop fields through gravity. The canal either feeds directly into the fields or into overnight balancing dams for storage. Balancing dams act as temporary reservoirs and help to ensure continuous supply of water to all irrigation water users in the scheme. Farmers access water from the balancing dams via distribution canals on specific days agreed upon by the scheme participants and block committees. Some tail-end blocks use a diesel pump to supplement their canal water by pumping directly from the Mooi River.

Multistage sampling was used to draw a sample of 307 smallholders from among the canal water users. A total of 246 respondents were sampled from 824 scheme members, which constitute $29.7 \%$ of the total number of irrigators in the scheme. Since the actual number of non-scheme members was not known, a simple random sampling approach was adopted to sample 61 respondents from households within the command of the MRIS canal. All the sampled farmers are irrigators, practising irrigation within and outside the scheme, and all rely on the MRIS canal. To ensure that a representative sample was drawn, the scheme was stratified into 3 segments (upper, middle, and tail-end) based on positions of individual farmers' irrigation plots along the main conveyance canal. The upper segment of the MRIS comprises of members farming in Blocks 1 to 5 , the middle segment comprises of members farming in Blocks 6 to 11, and the tail-end segment constitutes Blocks 12 to 15. Respondents were proportionally selected from each of the three sections based on the number of farmers in each segment of the scheme. A household questionnaire was used to extract data from the sampled farmers. Interviewees were contacted at their homesteads to ensure easy tracing of the farmers by using homestead numbers and mobile telephone numbers.

\section{Empirical methods of data analysis}

The study employed three main data analysis techniques: principal component analysis (PCA) for dimension reduction, Tobit regression for assessing the determinants of participation, and, lastly, ordered Probit regression to measure individual intensity of participation in irrigation water management.

Other studies, mostly in collective marketing (Fischer and Qaim, 2012), have considered participation as a choice and step-wise decision, where respondents either participate or not. Under such circumstances, binary choice models are applied to analyse the determinants. This study could not consider the binary option due to the multidimensional nature of activities involved in water management. A respondent might be participating in one activity and not in others; as such it is logical to generate a composite index that captures the greatest number of possible collective activities that farmers are expected to engage in. Participation in water management activities within the MRIS is mandatory for all members, although compliance and cooperation seems to be a challenge. More so, participation in canal water management in the MRIS is multi-dimensional; hence, PCA was used to generate a composite index of participation. The variables representing the various forms of farmers' participation in collective action are not orthogonal, hence PCA reduces the dimensionality of variables (Manyong et al., 2006) and decomposes variations in the variables included in the analysis into orthogonal components, each having a characteristic unique from the others (Dunteman, 1989; Fujiie et al., 2005).

Respondents ranked their participation level in a wide range of irrigation management activities. A total of 15 activities were identified, which were grouped into 5 main themes (Fig. 1), namely (i) labour-based participation - canal cleaning, canal repairs and pump repairs; (ii) financial-based participation - contributing finance towards infrastructure repairs and towards the running of the WUA; (iii) participation in decision making - attending meetings, lobbying, and contributing ideas in water related issues; (iv) information dissemination activities - distributing water-related information in the area; and (v) participation in regulation and control - reporting unlawful diversion of water, reporting theft of irrigation infrastructure, and reporting damages and water leakages along the major irrigation infrastructure. Participation in activities was ranked using a 5-point Likert scale from zero (0) if a farmer is not involved in a given activity, to four (4) if he/she is highly involved. The rankings were then used to compute the participation index (PI) using PCA for individual farmers in waterrelated activities.

Explicitly, the forms of participation in collective activities by farmers are assumed to have equal weights. This may be queried where smallholder farmers value the forms of contribution differently; for example, one farmer might value labour contribution more than financial contribution or attending meetings. Differences in value allocation might be emanating from different socio-economic status of respondents or the characteristics of the resource. The complexity of allocating specific values to the various forms of participation resulted in the current implicit assumption about equal weights. The PI was therefore used as a proxy to measure farmers' involvement in collective action. 
The PCA was also used to generate an incentive index based on benefits accrued from participating in collective water management activities. Water users ranked a total of 7 perceived benefits of participating in water management on a 5-point Likert scale from 0 (poor) to 4 (excellent). Some of the perceived benefits include reliability of water supply for agricultural needs, improvement in government support, improved capacity to lobby by water users, increased feeling of responsibility, reliability of water supply for non-agricultural activities, and improved access to canal water. The incentive index was then used as an independent variable to explain farmers' participation in collective action. The study hypothesised that incentives have a positive influence on the intensity of participation in collective action.

Following previous studies, e.g., Manyong et al. (2006) and Wang et al. (1997), a censored Tobit regression model was applied to estimate the factors influencing behaviour in collective water management $(Z)$, i.e., user attributes, physical or resource attributes, institutional attributes and incentives for the forms and level of participation (participation index) (Fig. 1). The PCA-derived composite index of participation $(\sigma)$ is the dependent variable. Given the right- and left-censoring at minimum $\left(\sigma_{\min }\right)$ and maximum $\left(\sigma_{\max }\right)$ score, respectively, the 2-limit Tobit model (Maddala, 1983; Wang et al., 1997) is specified as follows:

$$
\sigma_{i}^{*}=\beta^{\prime}\left(Z_{i}\right)+\varepsilon_{i}
$$

where:

$\sigma_{i}^{*}$ is an unobservable latent response variable

$Z_{i}$ is an observable vector of explanatory variables

$\beta$ is a vector of parameters to be estimated

$\varepsilon_{i}$ is a vector of independently and normally distributed

residuals with a common variance $\theta$.

Then the actual model can be represented as follows:

$$
\begin{aligned}
\sigma_{i} & =\sigma_{\min } \text { if } \sigma_{i}^{*} \leq \sigma_{\min } \\
& =\beta^{\prime}\left(Z_{i}\right)+\varepsilon_{i} \text { if } \sigma_{\min } \leq \sigma_{i}^{*} \leq \sigma_{\max } \\
& =\sigma_{\max } \text { if } \sigma_{i}^{*} \geq \sigma_{\max }
\end{aligned}
$$

With this specification of parameters of participation variables, the model can be estimated by maximising the following corresponding log-likelihood function (Maddala, 1983):

$$
\begin{aligned}
L(\beta, \theta)= & \prod_{\sigma_{i}=\sigma_{\min }} \Phi\left(\frac{\sigma_{\min }-\beta^{\prime} Z_{i}}{\theta}\right) \prod_{\sigma_{i}=\sigma_{i}^{*}} \frac{1}{\theta} \phi\left(\frac{\sigma_{i}-\beta^{\prime} Z_{i}}{\theta}\right): \\
& \times \prod_{\sigma_{i}=\sigma_{\max }}\left[1-\Phi\left(\frac{\sigma_{\max }-\beta^{\prime} Z_{i}}{\theta}\right)\right]
\end{aligned}
$$

where:

$\Phi$ and $\varnothing$ are the standard normal density and distribution functions, respectively.

Ordered Probit regression was then applied to assess the determinants of participation intensity in common pool water resource management by smallholder farmers. Based on individual rationality, which is influenced by resource, socio-economic status, incentives and institutional attributes (Fig. 1), respondents indicated that they either participate or do not participate in collective activities. For those that participate, their level of participation varies. Respondents' observed preference to take collective responsibilities was regarded as a key measure of participation intensity. As such, the intensity of participation in irrigation water management is an ordered dependent variable and categorically measured as: Category $0=$ User not participating at all (none) Category 1 = Not participating fully (poor) Category 2 = Participating as an ordinary member (good) Category 3 = Participating as a committee management member (very good)

Category 4 = Participating as a chairperson (Excellent)

Due to a limited number of respondents, Categories 3 and 4 were merged to improve the estimation of the model. According to Greene and Hensher (2008), the ordered Probit model takes into account the order value of the dependent variable, hence its adoption in this study. Intensity of participation in irrigation water management depends on certain measurable factors $\left(X_{i}\right)$ and certain unobservable factors $\left(\boldsymbol{\varepsilon}_{i}\right)$. The ordered Probit model was therefore estimated for the polychotomous dependent variable with 4 categories.

Following Wooldridge (2002), the ordered Probit model for $Y$ (conditional on explanatory variables $X_{i}$ ) can be derived from a latent variable model as follows:

$Y_{i}^{*}=\beta^{\prime} X_{i}+\varepsilon_{i}$, where $i=1, \ldots, N$, and

$Y^{\star}$ is unobserved, but what are observed are threshold

values of Y (Wooldridge, 2002), which in the present case would be:

$$
\begin{array}{ll}
Y=0 & \text { if } Y^{\star} \leq 0 \\
Y=1 & \text { if } 0<Y^{\star} \leq 1 \\
Y=2 & \text { if } 1<Y^{\star} \leq 2 \\
Y=3 & \text { if } Y^{\star} \geq 3
\end{array}
$$

The vector of independent parameter estimates is embedded in the coefficient vector $\beta$ (Wooldridge, 2002), consisting of demographic, institutional and socio-economic factors (Tables 1 and 2). The model adjusts better to a probability curve by using a normal distribution function to estimate the probability of a certain ranking (Greene and Hensher, 2008).

\section{RESULTS AND DISCUSSION}

\section{Descriptive statistics of variables used in the models}

An understanding of the household characteristics (Table 1) is important to contextualise farmers' behaviour in irrigation management. The average number of household members who are economically active and have indicated that they actually participate in agricultural activities is 2 people per household. Farming households utilise both family labour and hired labour to carry out their agricultural activities.

The average size of irrigation land accessed per household is 0.275 ha. This area increases to 0.405 ha per household after adding both irrigated and dryland fields that a household has use rights for outside the scheme. With regards to willingness to contribute finances towards canal maintenance, those who irrigate within the scheme (scheme-members) have a higher willingness to pay (R112.55/farmer per year) than those who irrigate plots located outside the scheme boundaries (nonscheme members) (R51.14). The difference between the two groups lies in the fact that the land being irrigated by the latter group was not part of the original infrastructure design of the irrigation scheme; this poses a possible water constraint to the land originally meant to be irrigated from the canal. However, irrigation of plots outside the scheme is necessitated by a shortage of irrigation land within the scheme. Although agricultural income levels are higher for scheme members 


\begin{tabular}{|l|c|c|c|}
\hline \multicolumn{3}{|c|}{ TABLE 1 } & \multicolumn{3}{|c|}{ Description of continuous variables, Mooi River Irrigation Scheme, KwaZulu-Natal, 2012/13 } \\
\hline Variable & $\begin{array}{c}\text { Total } \\
\text { sample } \\
(\boldsymbol{n}=\mathbf{3 0 7})\end{array}$ & $\begin{array}{c}\text { Scheme } \\
\text { members } \\
(\boldsymbol{n}=\mathbf{2 4 6})\end{array}$ & $\begin{array}{c}\text { Non-scheme } \\
\text { members } \\
(\boldsymbol{n}=\mathbf{6 1})\end{array}$ \\
\hline Average age of household head in years (AGE) & 56.99 & 56.50 & 58.80 \\
\hline Average number of household members who do agricultural work (FARMLABOUR) & 2.29 & 2.30 & 2.25 \\
\hline Average number of years in formal education (YEARSEDUCATION) & 2.52 & 2.30 & 3.38 \\
\hline $\begin{array}{l}\text { Average annual income from irrigation agriculture in Rands. (IRRIGCROP_INOME) } \\
\text { (April 2012 - April 2013) }\end{array}$ & 5694 & 6000 & 4000 \\
\hline Average irrigation area (ha) in the scheme per household (IRRGSCHEM_HA) & 0.275 & 0.330 & 0.048 \\
\hline Average area per household (ha) (irrigated plus dry land) (TOTAREA_HA) & 0.405 & 0.424 & 0.347 \\
\hline $\begin{array}{l}\text { Average amount farmers are willing and able to contribute for irrigation maintenance per } \\
\text { year in Rands (AVE_AMOUNT) (April 2012 - April 2013) }\end{array}$ & 100.35 & 112.55 & 51.14 \\
\hline
\end{tabular}

TABLE 2

Description of categorical variables, Mooi River Irrigation Scheme, KwaZulu-Natal, 2012/13 (source: survey data, 2013)

\begin{tabular}{|l|l|}
\hline $\begin{array}{l}\text { Ordered categorical }(\boldsymbol{n}=307) \\
\text { (The response variable) }\end{array}$ \\
\hline
\end{tabular}

Farmers' intensity of participation in common water management (LEVELPARTIC)

\begin{tabular}{|c|c|c|c|}
\hline \multicolumn{2}{|l|}{$\begin{array}{l}\text { Ordered categorical }(n=307) \\
\text { (The response variable) }\end{array}$} & \multirow{2}{*}{$\begin{array}{c}\begin{array}{c}\text { Total } \\
(n=307)\end{array} \\
54\end{array}$} & \multirow{2}{*}{\begin{tabular}{|c|}
$\begin{array}{c}\text { Percentage } \\
(\%)\end{array}$ \\
$17.6 \%$ \\
\end{tabular}} \\
\hline \multirow{4}{*}{$\begin{array}{l}\text { Farmers' intensity of participation in common water management } \\
\text { (LEVELPARTIC) }\end{array}$} & $0=$ Not participating at all (none) & & \\
\hline & $1=$ Not participating fully (poor) & 145 & $47.2 \%$ \\
\hline & $\begin{array}{l}2 \text { = Participating as an ordinary } \\
\text { member (good) }\end{array}$ & 92 & $30.0 \%$ \\
\hline & $\begin{array}{l}3 \text { = Participating as a committee } \\
\text { management member (very good) }\end{array}$ & 16 & $5.2 \%$ \\
\hline Variables & Units & $\begin{array}{c}\text { Total } \\
\text { sample } \\
\mathrm{n}=307\end{array}$ & $\begin{array}{c}\text { Percentage } \\
(\%)\end{array}$ \\
\hline \multirow{2}{*}{ Gender of household head (GENDER) } & $1=$ Male & 84 & $27.4 \%$ \\
\hline & $0=$ Female & 223 & $72.6 \%$ \\
\hline \multirow{2}{*}{ Training in irrigation water management (TRAINWATER A) } & $1=$ Yes & 111 & $36.2 \%$ \\
\hline & $0=\mathrm{No}$ & 196 & $63.8 \%$ \\
\hline \multirow{2}{*}{$\begin{array}{l}\text { Membership of individual irrigators to a water user association } \\
\text { (WUA) }\end{array}$} & $1=$ Yes & 26 & $8.5 \%$ \\
\hline & $0=\mathrm{No}$ & 281 & $91.5 \%$ \\
\hline \multirow{2}{*}{$\begin{array}{l}\text { Member has been involved in water-related conflict in the past year } \\
\text { (INVOLVCONF T) }\end{array}$} & $1=$ Involved & 210 & $68.4 \%$ \\
\hline & $0=$ Not & 97 & $31.6 \%$ \\
\hline \multirow{2}{*}{$\begin{array}{l}\text { Membership of a group/cooperative that uses water } \\
\text { (GRPUSEWATER) }\end{array}$} & $1=$ Yes & 75 & $24.4 \%$ \\
\hline & $0=\mathrm{No}$ & 232 & $75.6 \%$ \\
\hline \multirow{2}{*}{ Mode of water supply (IRRIGATYPE V) } & $1=$ Gravity & 228 & $74.3 \%$ \\
\hline & $0=$ Diesel/petrol-powered pumps & 79 & $25.7 \%$ \\
\hline \multirow{3}{*}{ Position of block along the main canal (BLOCKPOSIT N) } & 1 = Upper/head & 62 & $20.2 \%$ \\
\hline & 2 = Middle & 112 & $36.5 \%$ \\
\hline & $3=$ Tail-end & 133 & $43.3 \%$ \\
\hline \multirow{2}{*}{$\begin{array}{l}\text { Whether user often draws water directly from the Mooi River } \\
\text { (DRIVERWATER) }\end{array}$} & $1=$ Yes & 129 & $42.0 \%$ \\
\hline & $0=$ No & 178 & $58.0 \%$ \\
\hline \multirow{2}{*}{$\begin{array}{l}\text { Whether there is need for water measurement devices in the area } \\
\text { (WATERMEASUR) }\end{array}$} & $1=$ Yes & 136 & $44.3 \%$ \\
\hline & $0=$ No & 171 & $55.7 \%$ \\
\hline \multirow{2}{*}{$\begin{array}{l}\begin{array}{l}\text { Perception of irrigation water adequacy } \\
\text { (IRRIG_WATA } \sim \text { Y) }\end{array} \\
\end{array}$} & 1 = Adequate & 64 & $20.8 \%$ \\
\hline & $0=$ Inadequate & 243 & $79.2 \%$ \\
\hline \multirow{2}{*}{ Perceived effectiveness of the committee members (COMMIT_EFF T) } & $1=$ Effective & 188 & $61.2 \%$ \\
\hline & $0=$ Not effective & 153 & $49.8 \%$ \\
\hline \multirow{2}{*}{ Frequency of attending water-related meetings (FREQMEETINGS) } & $1=$ Regular attendance & 198 & $64.5 \%$ \\
\hline & $0=$ Less regular or not at all & 109 & $35.5 \%$ \\
\hline \multirow[b]{2}{*}{ Whether the respondent is a full-time farmer or not (OCCUPATION) } & $1=$ Full-time farmer & 174 & $56.7 \%$ \\
\hline & $\begin{array}{l}0=\text { Part-time/has other full-time } \\
\text { income-generating occupation }\end{array}$ & 133 & $43.3 \%$ \\
\hline \multirow{2}{*}{ Perception of infield water distribution (WAT_PERCEPT) } & $1=$ Fair & 105 & $34.2 \%$ \\
\hline & $0=$ Unfair & 202 & $65.8 \%$ \\
\hline
\end{tabular}

Perception of infield water distribution (WAT_PERCEPT) 
(R6 000 per/year) than non-scheme members (R4 000 per year), as with other schemes, income levels are generally lower than expected (Cousins, 2013; Sinyolo et al., 2014). However, the income differences between the groups cannot be attributed entirely to water access alone because some sources of variation, like farmer training, access to land and institutional aspects, could not be controlled. A detailed summary of the categorical variables is presented in Table 2.

The majority of the respondents were women (72.6\%), indicating active involvement of women in smallholder irrigation crop farming, and $56.7 \%$ of the respondents were full-time farmers. The general perception among farmers was that irrigation water supply was inadequate and unfairly distributed, as reported by $79.2 \%$ and $65.8 \%$ of the irrigators, respectively. Furthermore, a significant number of respondents (68.4\%) have also been involved in water-related conflicts in the area. The identified challenges might have a negative effect on farmer participation in collective management of irrigation. Both the continuous and the categorical variables in Tables 1 and 2 have been used as explanatory variables to estimate the Tobit and the ordered Probit regression models.

\section{Measures of participation in collective activities}

Seven principal components were extracted using Pearson correlations. By applying the Kaiser criterion, 3 components that had eigenvalues greater than 1 were retained. Table 3 presents the PCA results.

The first principal component (PC1) has a higher explanatory power and explains $58.67 \%$ of the variation in farmer participation in collective activities, with PC2 and PC3 explaining $21.56 \%$ and $18.05 \%$, respectively. The three PCs explained $98.28 \%$ of the variation in the data. The PC vector of the first component is economically meaningful because, unlike the other components' vectors, none of its coefficients is negative. Since each of the variables represents participation in each different activity of scheme management, the positive weights for all the variables in the first component vector can be taken as evidence that $\mathrm{PC} 1$ represents the aggregate variations due to the differing degrees of participation; hence $\mathrm{PC} 1$ was retained and then used to generate the participation index. The first retained component accounts for such a large percentage of the variance in the variables that it can be used alone without much loss in information (Manyong et al., 2006).

This first component (Table 3) is dominated by farmers' involvement in canal repairs as well as participation in decision-making activities. This indicates that the farmers who participate in water management are more involved in labour-based activities like canal repairs and maintenance. Such farmers are also involved in complementary activities like decision making through participating in meetings, reporting infrastructure theft as well as engaging authorities to resolve water-related challenges in the scheme. Since most of the activities in management of communal irrigation schemes are complementary in nature (Fujiie et al., 2005), they should be viewed as a whole, and water users must be encouraged to participate equally in all activities because failure or success of a particular activity affects the performance of the others. This can be an effective approach to ensure sustainable management of communal smallholder irrigation schemes.

TABLE 3

Collective participation index generation using PCA, Mooi River Irrigation Scheme, 2012/13 (source: survey data, 2013)

\begin{tabular}{|c|c|c|c|}
\hline & \multicolumn{3}{|c|}{ Principal component (PC) } \\
\hline & 1 & 2 & 3 \\
\hline Eigenvalues & 4.55 & 1.67 & 1.40 \\
\hline$\%$ of variance explained & 58.67 & 21.56 & 18.05 \\
\hline Cumulative $\%$ of variance explained & 58.67 & 80.23 & 98.28 \\
\hline Variables & \multicolumn{3}{|c|}{ Factor loadings } \\
\hline Main canal cleaning (CANALCLEAN) & 0.5095 & -0.4289 & 0.2288 \\
\hline Canal repairs (RPCANAL) & 0.7016 & 0.2364 & 0.0517 \\
\hline Repair of infield distribution canals (RPINFIELDC L) & 0.5924 & -0.3814 & 0.3153 \\
\hline Pump repairs (REPAIR_PUMP) & 0.1285 & 0.4917 & 0.5918 \\
\hline Contribute funds for pump repairs ( FUNDPUMPRP) & 0.1149 & 0.3301 & 0.6908 \\
\hline Contribute towards Water User Association (FUNDWUA) & 0.4579 & 0.3540 & 0.1204 \\
\hline Attend water-related meetings (ATTENDMEET $\sim \mathrm{G}$ ) & 0.5720 & -0.4129 & 0.1925 \\
\hline Attend irrigation training (ATTENIRIGT N) & 0.5834 & 0.2172 & -0.0578 \\
\hline Participating in meetings (IDEAS_INME S) & 0.6791 & -0.0745 & -0.0039 \\
\hline Engage water authorities (ENGAGEAUTHO) & 0.6004 & 0.1742 & -0.2319 \\
\hline Disseminate water-related information (INFODISTRIB) & 0.5202 & -0.4912 & 0.0811 \\
\hline Informally train others on water management (TRAINWATER A) & 0.6233 & 0.2104 & 0.0130 \\
\hline Report unlawful use of water (REPORTUNLA L) & 0.5983 & 0.2815 & -0.3415 \\
\hline Report equipment theft (REPOEQUIPT T) & 0.6005 & 0.3289 & -0.4057 \\
\hline Report damages and leakages (REPOLEAKAGES) & 0.5860 & -0.2913 & -0.1487 \\
\hline
\end{tabular}

Note: Five-point Likert scale values are: $0=$ never been involved; $1=$ low involvement; $2=$ average; $3=$ high; $4=$ very high 
It is also important to note the high factor loading of irrigation training as a complementary activity in scheme management. Most of the training is informal and mainly 'farmer to farmer' through irrigation information sharing. Informal training is very critical at smallholder level where access to extension services is at times a constraint (Cousins, 2013). Possible strategies to improve informal learning include short courses in crop production, irrigation management and farmers' days that can also facilitate information diffusion among irrigators at scheme level.

\section{Determinants of collective participation in irrigation water management}

Due to censoring in the use of a PCA-generated index as a dependent variable (Manyong et al., 2006), a 2-limit Tobit regression was estimated. The index of farmer participation in collective water management activities (PARTICIPA_X) was the dependent variable in the Tobit regression model. However, to ensure that the Tobit regression is correctly specified, postestimation tests were conducted. The test for multicollinearity among the explanatory variables was assessed using variance inflation factors (VIF), which were all below 10, with an average of 1.41. The robust standard errors were also estimated to correct for heteroskedasticity. Furthermore, normality is important and its violation results in unbiased and consistent estimates. The Jarque-Bera test for normality of the residuals was therefore performed. The results of the Tobit model are presented in Table 4.

Combinations of socio-economic, institutional and resource-related variables influence farmer participation in collective activities. The results indicate that location of plot (BLOCKPOSIT N), income contribution towards infrastructure maintenance (AVE_AMOUNT), income from irrigation farming (IRRIGCROP_ E), total household land ownership (TOTAREA_HA), frequency of attending irrigation management meetings (FREQMEETINGS), training in irrigation management (TRAINIRRIG), whether farmer has been involved in water-related conflicts within the 2012/13 farming season (INVOLVCONF T), farmer perception of the adequacy of irrigation water (IRRIG_WATA Y), perception of committee effectiveness (COMMIT_EFF T), amount of labour per household (FARMLABOUR), and years of formal education (YEARSEDUCA N ) significantly affect farmer participation in collective activities.

The results indicate that participation is influenced by farmers' plot location within the scheme. This can be due to unequal distribution of water among head and tail-end farmers, with the latter experiencing more water stress and hence lower incentive to participate than their head counterparts. This is consistent with the findings of Mbatha and Antrobus (2008), whose study noted that physical location of farmers along a watercourse, where water resources are diverted individually, contributes to economic inefficiencies due to resource misallocations, ceteris paribus, This suggests the need to focus on localised institutional arrangements to address distribution of water among head and tail-end farmers, which might improve participation in collective activities. This must also be accompanied by improving the amount of irrigation water available to the farmers.

The coefficients for the income a farmer receives from irrigation farming and the amount an individual farmer contributes annually towards water management activities are statistically significant. This makes economic sense, since farmers who

\begin{tabular}{|c|c|c|c|}
\hline \multicolumn{4}{|c|}{$\begin{array}{c}\text { TABLE } 4 \\
\text { Determinants of collective participation (Tobit results) } \\
\text { Mooi River Irrigation Scheme, 2012/13 (source: survey } \\
\text { data, 2013) }\end{array}$} \\
\hline & \multicolumn{2}{|c|}{ Tobit regression } & \multirow[b]{2}{*}{ VIF } \\
\hline & Coef. & $\begin{array}{l}\text { Robust } \\
\text { Std. Err. }\end{array}$ & \\
\hline AGE & -0.002 & 0.004 & 1.35 \\
\hline SCHEMEMBER P & 0.118 & 0.117 & 1.25 \\
\hline IRRIGATYPE V & 0.112 & 0.127 & 2.27 \\
\hline BLOCKPOSIT N & $0.145^{\star}$ & 0.084 & 3.74 \\
\hline AVE_AMOUNT & $0.002^{* * *}$ & 0.000 & 1.30 \\
\hline IRRIGCROP_ E & $0.000^{* * *}$ & 0.000 & 1.29 \\
\hline TOTAREA_HA & $0.229^{* * *}$ & 0.072 & 1.12 \\
\hline WUAMEMBER & 0.112 & 0.169 & 1.08 \\
\hline FREQMEETINGS & $0.286^{* * *}$ & 0.067 & 1.24 \\
\hline TRAINIRRIG & $0.365^{\star * *}$ & 0.094 & 1.24 \\
\hline NOWATER_OC E & 0.035 & 0.060 & 1.64 \\
\hline INCENTIVE_ X & 0.013 & 0.079 & 1.12 \\
\hline INVOLVCONF $\sim T$ & $0.093^{* *}$ & 0.043 & 2.48 \\
\hline IRRIG_WATA Y & $0.229^{*}$ & 0.129 & 1.58 \\
\hline COMITEFFEC $\sim \mathrm{E}$ & $0.146^{* * *}$ & 0.040 & 1.26 \\
\hline NON_FARMIC E & 0.000 & 0.000 & 1.26 \\
\hline GENDER & 0.083 & 0.096 & 1.12 \\
\hline FARMLABOUR & $0.039^{*}$ & 0.021 & 1.14 \\
\hline YEARSEDUCA N & $-0.036^{\star * *}$ & 0.014 & 1.35 \\
\hline _cons & $-1.759^{* * \star}$ & 0.419 & \\
\hline /sigma & 0.745 & 0.028 & \\
\hline \multicolumn{4}{|l|}{$F(19,287)$} \\
\hline Prob $>F$ & \multicolumn{2}{|c|}{$0.000^{* * *}$} & \\
\hline Pseudo $R^{2}$ & \multicolumn{2}{|l|}{0.191} & \\
\hline Uncensored observations & \multicolumn{2}{|l|}{299} & \\
\hline \multirow{2}{*}{$\begin{array}{l}\text { Left censored observations } \\
\text { Right censored observations }\end{array}$} & \multicolumn{3}{|c|}{$6($ Minimum $\leq-2.3)$} \\
\hline & $1(\mathrm{Ma}$ & mum $\geq 2$ & \\
\hline
\end{tabular}

receive more income from irrigation farming are more willing to participate in collective activities than those that receive less. Income generated in irrigation farming can be an indicator of the incentives available for farmers to participate in irrigation activities. Furthermore, irrigation training has an influence on farmer participation. Farmers with some form of training in water/irrigation scheme management participate more in scheme management activities. This highlights the importance of farmer training as being key to improving collective irrigation scheme management.

The estimated coefficient for total household irrigation land (TOTAREA_HA) positively affects farmers' participation in water management activities. As the size of irrigation land increases, demand for reliable water supply increases, and hence more effort is required by the farmer to achieve this. In the MRIS, irrigation water is not allocated according to land size per farmer or type of crops planted, but is based on a roster that allocates a specific number of irrigation days per block. Once the water gets to the block, it is then accessed on a 'firstcome first-take' basis, with a possibility of depriving water to irrigators who start irrigating late or are at the tail-end of the fields or canal. This is a possible indicator of both technical 


\begin{tabular}{|c|c|c|c|c|c|}
\hline \multicolumn{6}{|c|}{$\begin{array}{c}\text { TABLE } 5 \\
\text { The determinants of participation intensity in managing small-scale irrigation, } \\
\text { Mooi River Irrigation Scheme, 2012/13 }\end{array}$} \\
\hline \multirow[t]{2}{*}{ Variable } & \multirow[t]{2}{*}{$\begin{array}{l}\text { Estimated } \\
\text { coefficients }\end{array}$} & \multicolumn{4}{|c|}{$\begin{array}{c}\text { Marginal effects (dy/dx) when LEVEPARTIC } \\
\text { Equals }\end{array}$} \\
\hline & & 0 & 1 & 2 & 3 \\
\hline AGE & 0.001 & 0.000 & -0.000 & 0.000 & $2.36 \mathrm{E}$ \\
\hline SCHEMEMBER P & 0.34794 & -0.039 & -0.035 & 0.068 & 0.006 \\
\hline IRRIGATYPE V & $0.637^{\star}$ & -0.075 & $-0.059^{\star *}$ & $0.123^{\star}$ & $0.011^{\star}$ \\
\hline BLOCKPOSIT N & -0.150 & 0.015 & 0.018 & -0.030 & -0.00 \\
\hline AVE_AMOUNT & $0.006^{* * *}$ & $0.001^{\star * *}$ & $-0.001^{\star * *}$ & $0.001^{\star * *}$ & $0.000^{* * *}$ \\
\hline IRRIGCROP_ E & $-5.9 \mathrm{E}^{\star}$ & $6.17 \mathrm{e}^{*}$ & $7.06 \mathrm{E}^{\star}$ & $-0.000^{\star}$ & $-1.16 \mathrm{E}^{\star *}$ \\
\hline TOTAREA_HA & $0.582^{\star *}$ & $-0.061^{\star *}$ & $-0.069^{* *}$ & $0.118^{\star *}$ & $0.011^{\star *}$ \\
\hline WUAMEMBER & $3.657^{\star * *}$ & $-0.150^{* * *}$ & $-0.515^{\star * *}$ & $0.313^{* * *}$ & $0.352^{\star * *}$ \\
\hline FREQMEETINGS & -0.178 & 0.018 & 0.021 & -0.036 & -0.00348 \\
\hline TRAINIRRIG & -0.135 & 0.014 & 0.016 & -0.027 & -0.00262 \\
\hline NOWATER_OC E & $0.379^{* *}$ & $-0.039^{* *}$ & $-0.045^{\star \star}$ & $0.077^{\star \star}$ & $0.007^{\star}$ \\
\hline INVOLVCONF T & -0.086 & 0.009 & 0.010 & -0.017 & -0.002 \\
\hline INCENTIVE_ X & 0.190 & -0.020 & -0.023 & 0.039 & 0.004 \\
\hline IRRIG_WATA Y & -0.521 & 0.061 & $0.049^{\star *}$ & $-0.101^{\star}$ & -0.009 \\
\hline COMMIT_EFF T & -0.167 & 0.018 & 0.019 & -0.034 & -0.003 \\
\hline NON_FARMIC E & $5.64 \mathrm{E}$ & $-5.87 \mathrm{e}$ & $-6.70 \mathrm{E}$ & $1.15 \mathrm{E}$ & $1.10 \mathrm{E}$ \\
\hline GENDER & 0.353 & -0.035 & -0.046 & 0.073 & 0.007 \\
\hline FARMLABOUR & -0.003 & 0.000 & 0.000 & -0.002 & $-5.2 \mathrm{E}$ \\
\hline YEARSEDUCA N & $0.077^{\star}$ & $-0.008^{*}$ & $-0.009^{*}$ & $0.016^{*}$ & $0.002^{\star}$ \\
\hline \begin{tabular}{|c|c|} 
/cut1 & -.3104487 \\
/cut2 & 2.384402 \\
/cut3 & 5.595228
\end{tabular} & & & & & \\
\hline $\begin{array}{l}\text { Number of observations } \\
\text { Wald Chi-square (19) } \\
\text { Prob > Chi-square } \\
\text { Pseudo } R^{2} \\
\text { Log pseudo likelihood }\end{array}$ & $\begin{array}{l}=306 \\
=\quad 96.48 \\
=\quad 0.000 \\
=0.160 \\
=\quad-301.9\end{array}$ & & $\begin{array}{l}\text { Brant test fo } \\
\text { assumption } \\
\text { Chi-square } \\
\text { D.F } \\
P>\text { Chi-squa }\end{array}$ & $\begin{array}{l}\text { parallel li } \\
\quad=23.11 \\
=38 \\
=0.973\end{array}$ & \\
\hline
\end{tabular}

to minimise water-related conflicts, meetings can be regarded as informal training platforms through which sharing of waterrelated information among farmers takes place. Since early 2012, the Department of Water Affairs (DWA) has been offering capacity-building workshops to WUA committee members in the MRIS, in which some aspects of collective management of water are covered. Through attending water management meetings, non-members of the WUA can benefit from those that are currently attending the capacitybuilding workshops. The need for functional support institutions at local level is therefore noted, the absence of which might result in lack of cooperation by members. Intensity of participation of individual respondents in collective water activities was analysed, and the findings are presented in the following section.

\section{Participation intensity in irrigation water management}

The study expanded on the commonly used concept of participation, mostly measured as a binary choice variable, which is often critiqued for losing valuable information about intermediatelevel collective action. The level of participation was based on the individual participation status as observed at the time of data collection. Respondents indicated their level of involvement in water management at

Note: ${ }^{* * *},{ }^{* *}$ and ${ }^{*}$ denote significance at the $1 \%, 5 \%$ and $10 \%$ levels, respectively.

${ }^{(d)} d y / d x$ is for a discrete change of dummy variable from 0 to 1

and institutional failure in the scheme. The system should have been designed with proper water measurement devices to regulate flow allocation per farmer, enforceable at field level. Water meant for late irrigators or those not available to irrigate should rather be stored in the balancing dams /reservoirs for future use, instead of being used by a few farmers.

The conditions for successful collective action suggest that the establishment of the right institutions can create incentives that would make cooperation the rational choice. It has however been observed that, while these conditions are common to many successful collective action efforts (Agrawal, 2001), there may be other factors that influence the behaviour of people. As such, some of the institutional determinants of participation in collective activities include frequency of meeting attendance and perceived effectiveness of the scheme and block committees. Water users who frequently attend water management meetings and those who perceive the existing scheme committee to be effective in managing irrigation water resources are more likely to participate in collective activities. Besides local by-law enforcement, which is meant local level and were grouped into 4 groups, as given in Table 2. Participation intensity increases from not participating at all to high levels of participation as committee members. An ordered Probit model was used to identify the determinants of participation intensity by the respondents, and results are presented in Table 5.

Before interpreting the results of the full model, tests for model fitness were done. The ordered Probit model has a good fit to the data, as shown by a strong $F$-value $(p=0.000)$. The parallel line assumption of proportional odds was also tested using the Brant test. The results fail to reject the null hypothesis that the model without predictors is as good as the model with the predictors. Since the model did not violate the parallel line assumption, its use in this study was justified.

The results of the ordered Probit model indicated that irrigation type (IRRIGATYPE V), average contributions towards water management (AVE_AMOUNT), total irrigation area (TOTAREA_HA), membership of a water user association (WUAMEMBER), frequency of days without consistent supply of water per week (NOWATER_OCE) and 
years of education (YEARSEDICA N) have a statistically significant influence on participation intensity. As such, those respondents whose water supply is wholly supported by gravity are likely to participate more in water/irrigation scheme management than those with an additional system (pump system). During discussions with users, farmers highlighted that managing a pump is more complex, especially when mobilising participants to contribute money towards purchasing fuel. Water users would rather participate as committee members in a gravity-only system that they perceive to be less challenging than the pump system. This finding points to the fact that furrow irrigation systems, relying on gravity, are easy to manage compared to sprinkler and furrow systems powered by diesel pumps. This is consistent with findings by Crosby et al. (2000) that smallholder gravity-fed short furrow irrigation systems are better managed and more efficient for smallholder farmers in South Africa. Turral et al. (2010) also noted that irrigation technology must be appropriate to meet the agricultural, managerial, financial and economic needs and capacity of system operators and farmers. This is an important decision-making tool that can be of use in the current IMT and rehabilitation of smallholder irrigation schemes (RESIS) in South Africa. A focus on revitalising gravity-fed furrow irrigation systems, which farmers are willing and able to manage, might be a better policy option for smallholders in South Africa.

Farmers who contribute finances are likely to participate at higher levels, including being committee members, than non-contributors. The marginal effects indicate a negative influence of financial contributions to participation at lowerlevel categories as ordinary members (Category 0 and 1 ) and a positive influence of participation at higher levels as committee members (Categories 2 and 3). This can be attributed to financial accountability. Irrigators who contribute finances want to ensure that their finances are used appropriately; hence such farmers participate more, even in irrigation scheme meetings, either as ordinary or committee members.

Total irrigation area (TOTAREA_HA) and membership of a WUA (WUAMEMBER) are significant predictors of participation intensity. At the time of this study, there seemed to be a very low level of understanding of how formal institutions like WUAs operate, with some respondents not even knowing what a WUA is. Water users who are current members of the WUA participate more in water management activities than nonmembers. There is a $31.3 \%$ and $35.2 \%$ chance of WUA members participating regularly in collective activities as ordinary members (Category 2) and as committee members (Category 3). Some WUA members in the MRIS have attended capacitybuilding workshops offered by the Department of Water Affairs (DWA) on the importance of being active participants in water management through the local WUA. This could be the reason for a statistically significant influence of WUA membership on intensity of participation in water management. However, the detailed discourse of water institutions and their effect on water management and access at farm level are beyond the scope of this paper.

Theory predicts that users' demand for and dependence on a resource influences their participation in the collective management of that resource (Sserunkuuma et al., 2009). The regression results indicate that respondents who experience a high number of days without water per week (NOWATER OC E) participate more in water/scheme management in order to improve access to the resource. This suggests that farmers recognise the role of participation in water management activities to improve their level of water supply. However, it was anticipated that a negative coefficient would have meant that a high frequency of days without water discourages participation, and eventually users would cease irrigation farming in the long-run. The fact that it has a positive influence might represent a short-run effect of water scarcity on farmer participation. In the long-run, if the problem of water persists, farmers might quit farming as revealed by negative marginal effects for lowerlevel participants.

Intensity of participation is also influenced by the education level of the farmer. An increase in formal education increases intensity of participation in water/scheme management. Education level is a very critical aspect in making objective judgements on the importance of participation in group activities. However, farmers in the MRIS have low levels of formal education (2.5 years); hence there is a need to focus on literacy level development and irrigation training among irrigation water users as a strategy for improving collective management of the scheme.

\section{CONCLUSIONS AND RECOMMENDATIONS}

Understanding the factors affecting farmer participation in irrigation water management is crucial for formulating sustainable smallholder irrigation policies. This is relevant given the high rate of failure of smallholder schemes that were formerly funded and managed by the state. This has called for the withdrawal of government and the step-by-step transfer of management and ownership to the users. This study, therefore, employed collective action theory and econometric models to explore the determinants of participation in collective activities by farmers operating in a communally-managed scheme.

The study concludes that the success or failure of smallholder irrigation schemes depends on user participation in their management. An interplay of socio-economic, institutional and resource-based attributes greatly influences farmer participation in collective management of schemes. In view of the fact that irrigators who joined the local WUA revealed higher participation intensity compared to non-members, this suggests a need to increase farmer participation in formalised institutions that also expose them to water management training, through capacity-building programmes run by the government and other initiatives.

In cases where water supply is not adequate and is unreliable to meet scheme demand, technical interventions in the management of communal schemes, such as the infrastructure refurbishments and upgrading of scheme capacity, need to be complemented by institutional interventions, which can lead to improved financial contributions towards infrastructure maintenance by water users. This can be a positive step towards deepening the irrigation management transfer process, and building the capacity of water users through targeted training. Institutional arrangements in irrigation scheme management must also be tailor-made to take into account the low literacy levels among smallholder farmers.

\section{ACKNOWLEDGEMENTS}

The authors thank the Water Research Commission (WRC) for funding the study through project no. K5/1879//4 and the Institute of Natural Resources (INR) for project coordination and logistical support. Constructive comments from two anonymous reviewers are duly acknowledged. 


\section{REFERENCES}

AGRAWAL A (2001) Common property institutions and sustainable governance of resources. World Dev. 29 (10) 1623-1648.

ARUN G, SINGH DR, KUMARC S and KUMARD A (2012) Canal irrigation management through water users associations and its impact on efficiency, equity and reliability in water use in Tamil Nadu. Agric. Econ. Res. Rev. 25 409-419.

BACHA D, NAMARA R, BOGALE A and TESFAYE A (2011) Impact of small-scale irrigation on household poverty: empirical evidence from the Ambo district in Ethiopia. Irrig. Drain. 60 (1) 1-10.

COUSINS B (2013) Smallholder irrigation schemes, agrarian reform and 'accumulation from above and from below' in south Africa. J. Agrar. Change 13 (1) 116-139.

CROSBY CT, LANGE MD, STIMIE CM and STOEP IVD (2000) A Review of Planning and Design Procedures Applicable to SmallScale Farmer Irrigation Projects. WRC Report No. TT 478/10. Water Research Commission, South Africa,

FANADZO M (2012) Revitalisation of smallholder irrigation schemes for poverty alleviation and household food security in South Africa: A review. Afr. J. Agric. Res. 7 (13) 1956-1969.

FANADZO M, CHIDUZA C and MNKENI PNS (2010) Overview of smallholder irrigation scheme in South Africa. Relationship between farmer crop management practices and performance. Afr. J. Agric. Res. 5 (25) 3514-3523.

FISCHER E and QAIM M (2012) Linking smallholders to markets: Determinants and impacts of farmer collective action in Kenya. World Bank 40 (6) 1255-1268.

FUJIIE M, HAYAMI Y and KIKUCHI M (2005) The conditions of collective action for local commons management: the case of irrigation in the Philippines. Agric. Econ. 33 179-189.

GOMO T, MUDHARA M and SENZANJE A (2014) Farmers' satisfaction with the performance of the Mooi River Irrigation Scheme KwaZulu-Natal, South Africa. Water SA 40 (3) 1-10.

GREENE WH and HENSHER DA (2008) Modelling Ordered Choices. A Primer and Recent Developments. Version 4. New York University, New York.

HARDIN G (1968) The tragedy of the commons. Science 162 (3859) 1243-1248.

HASSAN MMU (2011) Analyzing governance reforms in irrigation: Central, South and West Asian experience. Irrig. Drain. 60 151-162.

ITO J (2012) Collective action for local commons management in rural Yunnan, China: Empirical evidence and hypotheses using evolutionary game theory. Land Econ. 88 (1) 181-200.

MADDALA GS (1983) Limited-Dependent and Qualitative Variables in Econometrics. Cambridge University Press, New York.

MANYONG VM, OKIKE I and WILLIAMS TO (2006) Effective dimensionality and factors affecting crop-livestock integration in West African savannas: a combination of principal component analysis and Tobit approaches. Agric. Econ. 35 145-155.

MBATHA CN and ANTROBUS GG (2008) Institutions and economic research: a case of location externalities on agricultural resource allocation in the Kat River basin, South Africa. Agrekon 47 (4) 470-491.

MNKENI PNS, CHIDUZA C, MODI AT, STEVENS JB and MONDE $\mathrm{N}$ (2010) Best management practices for smallholder farming on two irrigation schemes in the Eastern Cape and KwaZuluNatal through participatory adaptive research. WRC Report No. 578/2/00. Water Research Commission, Pretoria.

OLSON M (1965) The Logic of Collective Action: Public Goods and the Theory of Groups. Harvard University Press, Cambridge MA.

OSTROM E (1991) Rational choise theory and institutional analysis: Toward complemenarity. The Am. Polit. Sci. Rev. 85 (1) 237-243.

OSTROM E (1994) Rules, Games and Common-Pool Resources. University of Michigan, Ann Arbor.

OSTROM E (2007) Governing the Commons: The Evolution of Institutions for Collective Action. Cambridge University Press, New York.

OSTROM E (2010) Analysing collective action. Agric. Econ. 41 (1) $156-166$.

PERRET S (2002) Water policies and smallholder irrigation schemes in South Africa: a history and new institutional challenges. Water Polic. 4 (3) 282-298.

REINDERS FB, VAN DER STOEP I and BACKEBERG GR (2013) Improved efficiency of irrigation water use: A South African framework. Irrig. Drain. 62 (3) 262-272.

SABATIER PA (2007) Theories of the Policy Process. Westview Press, Boulder.

SINYOLO S, MUDHARA M and WALE E (2014) The impact of smallholder irrigation on household welfare: The case of Tugela Ferry irrigation scheme in KwaZulu-Natal, South Africa. Water SA 40 145-156.

SSERUNKUUMA D, OCHOM N and AINEMBABAZI JH (2009) Collective action in the management of canal irrigation systems: The Doho Rice Scheme in Uganda. In: Kirsten JF, Dorward AR, Poulton C and Vink N (eds) Institutional Economics Perspectives on African Agricultural Development. International Food Policy Research Institute (IFPRI), Washington D.C.

TURRAL H, SVENDSEN M and FAURES JM (2010) Investing in irrigation: Reviewing the past and looking to the future. Agric. Water Manag. 97 (4) 551-560.

VAN DER ZAAG P and RAP E (2012) The pivotal role of canal operators in irrigation schemes: The case of the canalero. Irrig. Drain. 61 (4) 436-448.

WADE R (1987) The management of common property resources: Collective action as an alternative to privatisation or state regulation. Camb. J. Econ. 11 95-106.

WANG Q, HALBRENDT C, KOLODINSKY J and SCHMIDT F (1997) Willingness to pay for rBST-free milk: a two-limit Tobit model analysis. Appl. Econ. Lett. 4 (10) 619-621.

WEIRICH P (2008) Utility maximization generalized. J. Moral Philos. $5282-299$.

WOOLDRIDGE JM (2002) Econometric Analysis of Cross Section and Panel Data. The MIT Press, Cambridge. 